US biotechnology

\section{Congress at odds over regulation}

\section{Washington}

ELECTION fever has turned criticizing the US government's plans for regulating biotechnology into a political spectator sport in recent weeks, with points awarded for arcane theoretical arguments from ecology and molecular biology. But the game turned acrimonious last week, with each side accusing the other of bias, and worse, over a report on the subject prepared by staff of the investigations and oversight subcommittee of the House of Representatives' Committee on Science and Technology. The government's proposals, published in June, are designed to provide a framework within which federal agencies could coordinate their regulation of biotechnology - and which would let the industry know where it stands.

The report is based on hearings held by the subcommittee during the past four months. Considering that it has not been released to the public and that few admit knowing its precise contents, it has engendered strong feelings. But defenders of the administration's "coordinated framework" for regulation published in June have been given a clue to what to expect by comments on the administration's proposals published by Representative George Brown (Democrat, California) and four other Democratic members of the subcommittee, including its chairman Harold Volkmer.

The comments are stridently critical of the "coordinated framework" and have given rise to alarm that the formal report will have a "negative tone". One reason for that fear is that the report, although without direct legislative impact, might influence the forthcoming lawsuit against the administration brought by environmental activist Jeremy Rifkin. Rifkin claims that the "framework" does not meet the requirements of the Environmental Policy Act. The comments also contain errors of fact, according to Dr David Kingsbury, head of the Biotechnology Science Coordinating Committee, which has the job of implementing the "framework". Staff say, however, that there are important differences between the congressmens' comments and the forthcoming report.

Last week, the full Science and Technology Committee balked at giving its approval to the staff report, with minority Republicans saying the work was seriously flawed. An attempt to shelve the report until next year was defeated, however, and staff now expect approval, possibly with some minor changes, before Congress adjourns this week. Volkmer, who represents Missouri, supports the staff report. Observers point out that the Monsanto Company, which has received un- favourable publicity over its proposals to field-test a genetically engineered microbial pesticide, is prominent in the state, and that memories of Times Beach, where industrial pollution forced a community to be evacuated, still linger.

One particular scientific issue seems to have divided Democrat from Republican on the subcommittee: whether recombinant microorganisms whose new DNA includes only non-coding regulatory sequences should be exempt from high-level safety review before release into the environment. The administration, in the "framework", says they should. But in formal comments to the White House, Monica Riley of the American Society for Microbiology (ASM) said that there are known cases of foreign regulatory sequences affecting an organism's host range, and that they can affect specificity. The society would not choose automatically to exclude such recombinant organisms from high-level review. Other criticisms relate to exemptions for opportunistic pathogens.

Riley's comments, and testimony in Congress have earned ASM some criticism. In a letter addressed to ASM president Dr Jean Brenchley and dated 3 September, Winston Brill, vice-president for research at Agracetus Inc., and Ronald Cape, chairman of Cetus Corporation, say the ASM position is not supported by "the knowledgeable majority" and that "the portions of the ASM testimony [to the subcommittee] that are incorrect should be corrected by ASM; however, it may be impossible to retrieve the situation". Harlyn Halvorson of Brandeis University, chairman of the relevant ASM committee, said a reply to Brill and Cape's "arrogant" letter was being drafted but that the society was unlikely to change its position.

Meanwhile, the Office of Science and Technology Policy is weighing an 18-inch stack of comments it has received on the "framework", which outlines possible regulatory roles of all federal agencies involved in biotechnology (see Nature 323, 387 ; 1986). Although most of the comments are less harsh than those of Representative Brown and his colleagues, the complex proposals have given rise to numerous criticisms. One possibility, prompted in part by researchers' concern about the different sets of research guidelines envisaged in the "framework", is a uniform agency-wide set of recombinant DNA research guidelines that would encompass both those of the National Institutes of Health and proposals put forward by the Department of Agriculture. That proposal will shortly be considered by the Biotechnology Science Coordinating Committee.
Soviet education

\section{Central role for the universities}

THE Soviet minister of higher and specialized secondary education is "completely dissatisfied" with the research output of the higher education sector. Minister Gennadii Yagodin says that although the higher education sector employs some 35 per cent of the country's scientists (including about half of all the doctors of science), it is responsible for only 10 per cent of the total Soviet research effort. This, the minister admitted, is not entirely the fault of the universities, "but also their plight", because in recent years serious deficiencies have been allowed to develop in the "material and technical base" (buildings and equipment) of the higher education sector. Nevertheless, whoever is at fault, the fact remains that the university research sector is failing to "justify itself within the state".

The Politburo of the Central Committee of the Communist Party recently issued a set of guidelines for the restructuring of higher education, Yagodin said, and during the coming academic year, the universities and higher educational establishments will have to take the first step towards this "restructuring".

But at the planning level, the first step seems to be at a standstill. For the first time for many years, the total number of universities and institutes of higher education in the Soviet Union is being held steady, at 894, with a total student body of around 5 million. This, Yagodin explained, marks a shift in emphasis from quantity to quality. "Negative qualities", he said, have developed in Soviet higher education in recent years because of an emphasis on "quantitative indicators"

At the research level - the target of Yagodin's (and the authorities') particular disapproval - research topics are to be "revised" to make them more useful for practical purposes, and undergraduates are to be encouraged to participate in their instructors' research projects.

Yagodin's remarks seem to reveal a new official emphasis and upgrading of the role of the universities. For decades, the Soviet Academy of Sciences has been routinely hailed as the leader and coordinator of the country's research effort, whether in pure or applied science. While not detracting from this role, Yagodin, however, in an interview on Soviet television, stressed that the universities have a particular contribution to make. In the higher education sector, he said, there is a unique opportunity for interdisciplinary contacts between pure and applied sciences, economics and "the organization of production" - what in the West would be called business studies.

Vera Rich 